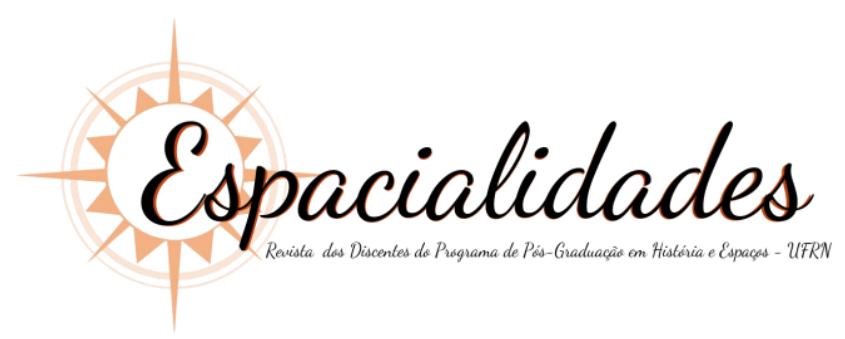

\title{
DOENÇA E ESPACIALIDADE NO ÉDIPO TIRANO DE SÓFOCLES
}

Disease and spatiality in Sophocles' Oedipus Tyrannus

Mateus Dagios ${ }^{1}$

Artigo recebido em: 02/08/2020.

Artigo aceito em: 25/09/2020.

\section{RESUMO:}

O artigo proposto procura desenvolver uma reflexão sobre a doença e o espaço na tragédia grega. $\mathrm{O}$ artigo insere-se na temática da doença (nósos) e de suas representações para problematizar a tragédia Édipo Tirano (427 a.C.) de Sófocles em relação à peste ocorrida entre 430 e 426 a.C em Atenas. Parte-se da hipótese de que a peste ressignificou a maneira como Atenas percebia suas instituições sociais. O texto realiza uma análise do vocabulário trágico e das relações entre doença e espaço desenvolvidas na peça.

PALAVRAS-CHAVE: Doença; Espaço; Tragédia; Peste; Édipo.

\section{ABSTRACT:}

This paper aims to examine disease and space in Greek tragedy, building on studies about disease (nósos) and its representations, in an analysis of Sophocles's Oedipus Tyrannus (427 BCE) in relation to the plague that afflicted Athens between 430 and 426 BCE. Our starting hypothesis is that this plague transformed how Athens perceived their social institutions. This study examines tragic vocabulary and the relations between disease and space developed in the play.

KEYWORDS: Disease; Space; Tragedy; Plague; Oedipus.

1 Doutor em História pela UFRGS. Lattes: http://lattes.cnpq.br/8420263129072679. E-mail: mateusdagios@yahoo.com.br. 
Meu tema não é a doença física em si, mas os usos da doença como figura ou metáfora.

Susan Sontag $-A$ doença como metáfora

\section{Introdução}

A pandemia da COVID-19 traçou uma linha em nossa sensibilidade. A ressignificação das posturas e das práticas cotidianas desenvolveu novas sínteses de relação entre o eu e o outro, habitar e estar isolado, produzir e sobreviver. Um novo vocabulário é experimentado para dar a dimensão da experiência de viver uma pandemia. Expressões como "novo normal" ou "próximo normal" instalam-se e aliviam o desconforto. A doença passa a organizar a coletividade, a redefinir espaços e mesmo aqueles que não estão enfermos são absorvidos por uma experiência coletiva.

A investigação histórica não é indiferente às pressões sociais e tampouco consegue ser neutra em seu ângulo de problematização. Pensar as dimensões de uma História das doenças torna-se a ordem do dia em uma época de pandemia. Desde a década de 1970, historiadores como Jacques Le Goff articulam bases epistemológicas de uma história das enfermidades que coloca o homem no centro da experiência social da doença: “A doença pertence não só à História superficial dos progressos científicos e tecnológicos como também à História profunda dos saberes e das práticas ligadas às estruturas sociais, às representações, às mentalidades (LE GOFF, 1997, p. 7-8). Pauline Labey defende que essa história deve articular a antropologia do corpo e a antropologia da doença: “O tema central deve ser o homem enfermo, trabalhando com as implicações de uma situação patológica particular, apresentada nas fontes como um desequilíbrio corporal que dissocia o doente do resto da comunidade" (LABEY, 2010, p. 7, tradução nossa) $)^{2}$.

\footnotetext{
${ }^{2}$ No original: "Le thème central doit être l'homme malade, en travaillant sur les implications d'une situation pathologique particulière, présenté dans les sources comme un déséquilibre corporel qui dissocie le malade du reste de la communauté."
} 
A doença como fenômeno tornou-se um problema multidisciplinar, que articula tanto ciências da saúde, do desenvolvimento e humanas. Laplantine define a experiência da doença com singular ambiguidade: é "ao mesmo tempo o que há de mais individual e de mais íntimo no ser humano e o que é mais repleto de social" (LAPLANTINE, 1991, p. 145). Problematizar as enfermidades não é apenas catalogar sintomas ou descrever seus efeitos sociais, mas percebê-las como um referencial simbólico de organização, criador de representações e configurador de espaços, conjugando fatores como corpo, dor, sofrimento, saúde e posturas. O doente é colocado em uma rede de significados que articula discursos sobre sua condição e a sociedade, abordando definições de saúde, velhice e morte.

O artigo proposto insere-se na temática da doença (nósos) e de suas representações para problematizar a tragédia Édipo Tirano (427 a.C.) de Sófocles em relação à peste ocorrida entre 430 e 426 a.C. Essa tragédia de Sófocles consolidou-se como um importante ícone cultural da experiência estética do Ocidente. Em um momento de crise e experiência de confinamento, torna-se necessário retornar a ela e inquerir questões. A investigação é conduzida por duas perguntas: 1. Qual é a importância da nósos como elemento de representação na tragédia Édipo Tirano? 2. Como a nósos se configura no texto como um elemento espacial da Tebas descrita por Sófocles?

Parte-se da hipótese de que a peste (430-426 a.C.) ressignificou a maneira como Atenas percebia suas potencialidades, principalmente o regime democrático ${ }^{3}$. A experiência de uma doença coletiva durante o conflito do Peloponeso (431-404 a.C.) reconfigurou a cidade, mergulhando Atenas em uma profunda crise de significados e valores. A peste, como veremos, é descrita por Tucídides como uma

${ }^{3}$ É fundamental considerar a experiência democrática grega em seu contexto histórico, mesmo que seja excludente para as demandas contemporâneas. Para um debate aprofundado, consultar FINLEY, 1988. 


\section{Espacialididades}

força "anarquizante" que desintegrava espaços civilizatórios e deixava os cidadãos confusos em relação às origens e consequências desse mal.

Para dimensionar a percepção de Atenas frente à peste, atentamos para o vocabulário trágico da peça de Sófocles, comentando os usos do termo nósos. Do ponto de vista teórico da tragédia grega, partimos das contribuições de Jean-Pierre Vernant e Christian Meier. No que concerne à doença (nósos), avaliamos como necessárias as noções defendidas por Mitchell-Boyask, que assinala que a partir dos anos iniciais da peste começou a ser proeminente na tragédia um vocabulário da doença. Sobre a questão da espacialidade no texto trágico, partimos do livro The Play of Space de Rush Rehm.

É preciso pontuar a singularidade do espetáculo trágico e como a tragédia marca um engajamento social, aglutinando dimensões ritualísticas e cívicas. O espetáculo trágico inseria-se em um contexto institucional: possuía dias (as festas consagradas ao deus Dioniso), lugar (o teatro em seu espaço físico) e público (os cidadãos atenienses). Tomamos a tragédia como uma invenção da cidade, um espetáculo de caráter cívico-religioso feito de cidadãos para cidadãos, que na interpretação do mito o reconstrói para abordar temas significativos para a vivência coletiva. Como escreve Marshall, “a representação trágica mimetiza memórias, possibilidades e tensões características da história cultural grega" (MARSHALL, 2007, p. 50).

O mito de Édipo é principalmente referenciado pela apropriação psicanalítica. Mas o que nos interessa não são apropriações modernas que privilegiam sentidos projetados independentemente do contexto social no qual a obra foi desenvolvida. Retomamos o emblemático debate de Jean-Pierre Vernant no texto Édipo sem Complexo, que reconhece a pertinência de outros usos para o material mitológico, mas o que problematizamos pertence à esfera dos estudos históricos em relação à tragédia como fonte, ou seja, “o pensamento social próprio da cidade no século V, com as tensões, as contradições que surgem nela, quanto a chegada do 
direito e as instituições da vida política questionam no plano religioso e moral, os antigos valores tradicionais" (VERNANT, 1999a, p. 55).

O texto divide-se em três partes: 1. A espacialidade da tragédia grega, em que é apresentado o sentido social do espetáculo trágico e a pertinência de discutir espaço na tragédia; 2. A nósos no vocabulário trágico, em que é discutida a doença no vocabulário trágico; 3. Doença e espacialidade no Édipo Tirano, em que se discutem partes específicas da tragédia referentes ao vocabulário da doença e ao percurso de Édipo em relação à enfermidade de Tebas.

\section{A espacialidade da tragédia grega}

É preciso considerar que o teatro assume na modernidade uma característica pessoal de engajamento, uma determinada reflexão sobre o que consideramos arte. Ir ao teatro em princípio é uma escolha, que fazemos considerando sua importância e dimensão estética. Na Atenas do século V a.C., o teatro pertencia ao espaço da cidade, estava presente na paisagem. Não era possível se esquivar da experiência ritualística que englobava o que chamamos de Festivais Dionisíacos. O teatro grego como instituição da pólis engloba diversas vivências e espacialidades.

Rush Rehm, no livro The Play of Space: Spatial Transformation in Greek Tragedy, aponta três grandes relações entre a tragédia e o espaço no teatro grego. A primeira refere-se à dimensão física, tratando da acústica e das possibilidades cênicas: "O espaço "permite" o que vemos e ouvimos durante um espetáculo teatral, oferecendo um contexto (principalmente) visual e acústico para relacionar objetos, corpos, personagens e suas manifestações na ação dramática” (REHM, 2002, p. 2, tradução nossa) ${ }^{4}$. A segunda é a construção imagética do cenário: “O espaço também

\footnotetext{
${ }^{4}$ No original: "Space "allows for" what we see and hear during a theatrical performance, providing a (primarily) visual and acoustic context for relating objects, bodies, characters, and their manifestation in dramatic action."
} 
"se constitui" na extensão de objetos e corpos no teatro, algo como a "aura" deles vista em termos materiais e não imaginários” (REHM, 2002, p. 2, tradução nossa) ${ }^{5}$. A terceira é um elemento dramático (no caso de Édipo, a cidade de Tebas e sua geografia):

Espaço é uma designação abrangente que inclui lugares, locais, regiões, características geográficas etc., sejam eles presentes, representados ou mencionados durante um espetáculo. Aquilo que não está literalmente presente pode "se fazer presente" no espaço do teatro, quando (por exemplo) uma personagem dramática evoca de forma poderosa o lugar de onde ela vem (REHM, 2002, p. 2, tradução nossa) ${ }^{6}$

As configurações do espaço não podem ser esquecidas quando problematizamos uma tragédia grega. Dumanoir entende a dimensão espacial como configuradora dos significados da tragédia: “o espaço trágico integra uma dimensão virtual que influencia constantemente o espetáculo e também a estrutura dramática" (DUMANOIR, 1998, p. 59, tradução nossa) ${ }^{7}$. O problema do espaço, seja do lugar ocupado pelo teatro dentro da dinâmica da cidade grega ou do espaço simbólico na peça, é essencial para uma compreensão do fenômeno trágico grego. A tragédia como celebração cívica-ritualística é fruto dos espaços da cidade e apresenta para a pólis também uma reflexão sobre sua espacialidade. As tragédias colocam o mito em dimensão de performance em espaços da cidade, como a assembleia ou ágora, que reatualizam os espaços míticos.

As apresentações ocorriam durante o ano nas três festas em homenagem ao deus Dioniso: as Leneias, no final de janeiro, para as quais se interrompiam os trabalhos do campo, do comércio e da navegação de forma que os cidadãos se dedicassem exclusivamente às festividades; as Grandes Dionisiacas, no final de março,

\footnotetext{
${ }^{5}$ No original: "Space also "comes to be" in the extension of objects and bodies in the theater, something like their "aura" viewed in material and not imaginary terms."

${ }^{6}$ No original: "Space is an umbrella term that covers places, locations, regions, geographical features, and so on, whether present, represented, or referred to during a performance. That which is not literally present can "come to presence" in the space of the theater, when (for example) a dramatic character powerfully evokes the place from which he or she arrives."

${ }^{7}$ No original: "l'espace tragique intègre une dimension virtuelle qui influence constamment le spectacle mais aussi la structure dramatique."
} 
traziam grande número de viajantes para Atenas; as Dionisíacas Rurais, que aconteciam em dezembro em regiões da Ática (CUSSET, 1997, p. 12-3). No edifício do teatro consagrado a Dioniso, era reservado um lugar para um altar do deus contendo uma imagem sua; no centro da orkhéstra, havia um altar de pedra em sua homenagem; e nas arquibancadas, um trono esculpido era reservado ao sacerdote de Dioniso (VERNANT, 1999b, p. 158).

As festividades em honra a Dioniso serviam para conciliar aspectos políticos e identitários da pólis. As peças eram escolhidas mediante um concurso dirigido pelo Arconte Epônimo, responsável por recrutar os atores e membros (coreutos) dos três coros, um de cada tragédia apresentada. Os coreutos eram dirigidos pelo chefe do coro, o corifeu, que tinha grande prestígio e compartilhava da glória do poeta em caso de vitória. Meier apresenta-nos o seguinte quadro para compreendermos o elemento agregador das festas:

As Grandes Dionisíacas começam pelo retorno solene da velha estátua de madeira do deus, que foi levada previamente para um bosque sagrado fora da cidade; elas prosseguem com uma brilhante procissão, para a qual cada uma das cidades da Confederação deve enviar um grande falo de madeira. Depois há os sacrifícios, em que abundam a carne e o vinho; depois, desfila um cortejo alegre e turbulento (MEIER, 2004, p. 70, tradução nossa) ${ }^{8}$.

Infelizmente, não nos restam evidências históricas que abarquem a totalidade das dimensões performáticas e ritualísticas nos festivais dionisíacos. Entretanto, o texto trágico permite acessar uma parte do imaginário grego do século $\mathrm{V}$ a.C. $\mathrm{O}$ vocabulário trágico, apesar de ambíguo, ecoa intencionalidades semânticas que fazem referência ao debate de temas públicos atenienses. Christian Meier defende que a pluralidade do vocabulário e o esforço coletivo para encenar a tragédia fazem com

\footnotetext{
${ }^{8}$ No original: "Les Grandes Dionysies commencent par le retour solennel de la vieille statue en bois du dieu, que l'on a, au préalable portée dans un bois sacré en dehors de la ville; elles se poursuivent par une brillante procession, pour laquelle chacune des cités de la Confédération doit envoyer un grand phallus de bois. Puis ce sont des sacrifices, où abondent la viande et le vin; après quoi défile un cortège joyeux et turbulent."
} 
que ela possa ser compreendida como uma arte política, pelo seu engajamento social (MEIER, 2004).

Os textos trágicos são compostos por vocabulário político e religioso, cuja presença e interação formam parte significativa das discussões postas em cena. Goldhill observa no discurso trágico a articulação de duas esferas gerais de linguagem:

\begin{abstract}
A linguagem trágica combina então vocabulário e tropos contemporâneos das instituições públicas da cidade com elementos de grandeza heroica com origem tanto na poesia épica do passado como no esplendor sacro dos ritos religiosos. Como a tragédia está tão preocupada com recontar as histórias do passado para a cidade contemporânea, essa tensão entre registros diferentes é uma dinâmica altamente significativa do gênero (GOLDHILL, 1997, p. 135, tradução nossa) ${ }^{9}$.
\end{abstract}

O espaço do teatro grego ficava ao ar livre e em seu centro ficava a orkhéstra, em que se erguia um altar, a thymele, em homenagem a Dioniso. O coro realizava sua performance na orkhéstra com danças. Ali se mantinha a unidade dessa personagem coletiva e também se desenrolava boa parte do espetáculo. Atrás ficava a skenê, que no decorrer do século $\mathrm{V}$ a.C. foi se desenvolvendo, passando a evocar fachadas de palácio ou outras paisagens míticas. A plateia ficava na encosta da colina, inicialmente composta por arquibancadas de madeira, que foram crescendo até se tornarem uma majestosa estrutura de pedra (GRIMAL, 1986, p. 15-18). Para Rehm, a intersecção entre espaço e texto pode propiciar uma experiência nova, por possibilitar visualidades e ritualizações coletivas, o que marcou uma revolução nas sensibilidades: "O espaço do teatro permite que algo ganhe vida e corpo, e nesse processo imaginação e criatividade misturam-se com realidades inabaláveis (e frequentemente brutais) da produção teatral" (REHM, 2002, p. 10, tradução nossa) ${ }^{10}$.

9 No original: "Tragic language, then, combines contemporary tropes and vocabulary of the public institutions of the city with elements of heroic grandeur which stem both from the epic poetry of the past and the sacral splendour of religious rite. Since tragedy is so concerned with retelling the stories of the past for the contemporary city, this pull between different registers is a highly significant dynamic of the genre."

${ }^{10}$ No original: "The space of the theater allows for something to come to life in the flesh, and in that process imagination and creativity merge with unshakable (and often brutal) realities of theatrical production. 
A espacialidade visual do teatro era radicalmente diferente da nossa percepção moderna de palco. O teatro contemporâneo geralmente é abrigado das intempéries naturais, e todos os efeitos podem ser construídos com luzes ou climatizações especificas. A peça desenvolve-se com o palco iluminado e o público na escuridão. No teatro grego, a plateia via seus semelhantes e um mundo comum à sua frente. O chão da orkhéstra era o local em que os atores atuavam e o coro desenvolvia suas danças, mas em uma linha espacial que se estendia na cidade e encontrava a paisagem em seu horizonte (REHM, 2002, p. 16). Tal experiência integrava a cidade ao teatro, permitindo que a sensação de coletividade não fosse diluída. O teatro antigo não é uma experiência individual, mas uma proposta coletiva que integrava o ritualístico e o cívico.

O vocabulário mítico é essencial à linguagem trágica e a essa proposta. A tragédia reinterpreta o mito, revestindo-o com problemas ou conflitos vividos na cidade pelos cidadãos. Michael J. Anderson destaca que há na tragédia uma reconfiguração ateniense do mito, usando-o para exame de tensões e desordens nas crenças e valores que ele encarna: "a tragédia grega em particular examina essas instituições e valores pela dramatização de momentos de crise extrema, conflito violento e angústia emocional, momentos em que valores tradicionais são ameaçados e vínculos sociais entram em colapso" (ANDERSON, 2005, p. 124, tradução nossa) ${ }^{11}$.

Peter H. Burian (1997) salienta a complexidade do discurso mítico utilizado nas tragédias, caracterizando-o como um repertório limitado, mas altamente flexível, cujo uso repetido mas sempre transformado revela o caráter inerentemente intertextual das tragédias. Outros poetas compunham tragédias com o mesmo mito. Não foi apenas Sófocles que desenvolveu uma versão trágica do mito de Édipo. Ésquilo e Eurípides também utilizaram Édipo como personagem em outras tragédias, que infelizmente se perderam. O emprego dos mitos pelos poetas trágicos,

11 No original: "Greek tragedy in particular examines these institutions and values by dramatizing moments of extreme crisis, violent conflict, and emotional distress, moments in which traditional values are threatened and social bonds break down." 
reconfigurando elementos conhecidos, faz dos textos versões em que as variações são altamente significativas, pois jogam com as referências e as expectativas:

\begin{abstract}
A forma e as ênfases específicas de um enredo trágico, como o produto de variação na forma e nas ênfases tanto de material lendário conhecido como de elementos formais familiares, pode direcionar ou deslocar forçosamente a atenção dos espectadores, confirmar, modificar ou mesmo subverter suas expectativas (BURIAN, 1997, p. 179, tradução nossa) ${ }^{12}$.
\end{abstract}

A tragédia é uma performance de repetição e inovação em que os poetas criam redes intertextuais de similaridades e diferenças nas quais o rompimento das expectativas é um elemento crucial. É importante considerar "não somente a flexibilidade dos padrões de enredo, mas as tensões geradas pelas lacunas, reais ou potenciais, entre as expectativas geradas pelos padrões e a sua realização em enredos específicos” (BURIAN, 1997, p. 190, tradução nossa) ${ }^{13}$. Essa dissonância é um dos elementos que levaria o público a reconsiderar os mitos e os significados postos em cena.

Assim, os temas e os heróis míticos não eram simplesmente reproduzidos pelos poetas, mas reelaborados e problematizados. Não só os temas e as histórias míticas mas também a própria forma da linguagem mítica era utilizada na reelaboração do mito no espaço da pólis: "a tragédia reapresenta as histórias do passado heroico homérico para a pólis do presente: o modo pelo qual a linguagem épica constantemente informa a linguagem trágica é integral para esse processo de reescrita" (GOLDHILL, 1997, p. 130, tradução nossa) ${ }^{14}$.

\footnotetext{
${ }^{12}$ No original: "The particular shape and emphases of a tragic plot, as the product of variation in the shape and emphases both of known legendary material and of familiar formal constituents, can forcefully direct or dislocate spectators' attention, confirm, modify, or even overturn their expectations."

13 No original: "the interesting thing is not just the flexibility of story patterns, but the tensions generated by gaps, real or potential, between the expectations raised by the patterns and their fulfilment in specific plots."

${ }_{14}$ No original: "Tragedy re-presents the tales of the Homeric, heroic past for the polis of the present: the way in which epic language constantly informs tragic language is integral to this process of rewriting."
} 


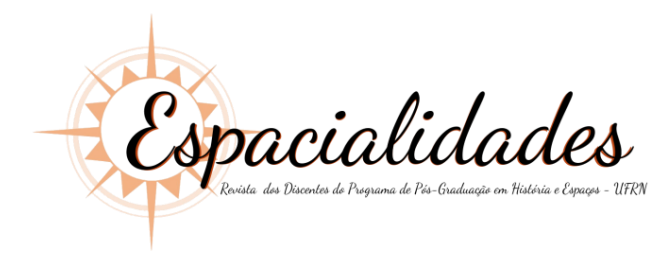

As tragédias gregas trazem em seus enredos temas que abordam questões coletivas, que são discutidas pelo coro e ressignificadas pela cidade. Por mais que as personagens sofram brutalidades ou reviravoltas do destino, seu mal particular está conectado à cidade. A profecia de que Édipo mataria o pai e desposaria a mãe só se torna um problema à medida que sua presença amaldiçoa Tebas, assim como o destino do corpo de Polinices, irmão de Antígona, se torna um problema à medida que envolve uma ordem pública de Creonte. O espaço público é um problema que se sobrepõe à esfera privada.

A arte política da tragédia grega constitui-se no texto trágico à medida que o poeta constrói a tragédia em discussão com a identidade da pólis e à medida que a pólis compreendida na comunidade de cidadãos, apesar de modernamente excludente, consegue compor um espaço no qual os problemas da comunidade são transformados em mitos reatualizados para o contexto político do século $\mathrm{V}$ a .C.:

a experiência e a problemática política podiam então justamente determinar uma nova interpretação do mito. Os problemas da atualidade podiam então ser abordados, de maneira mais ou menos direta, e o mito era ilustração deles. É nestes momentos que a tragédia reflete para nós um aspecto do pensamento político da época; ela exerce então verdadeiramente a sua função educativa essencial: instância globalmente neutra, ela atualiza os problemas ou as realizações da pólis; traz à consciência a essência mesma do político e exprime talvez certas advertências de ordem geral (MEIER, 1996, p. 144, tradução nossa) ${ }^{15}$.

A experiência da tragédia como fenômeno social grego, com regras e características estruturadas em um sistema de festas públicas de caráter religioso, trouxe um tipo de espetáculo que problematiza para uma comunidade questões específicas. Como veremos no próximo tópico, a experiência da peste não escapou da percepção do teatro grego.

\footnotetext{
${ }^{15}$ No original: "l'expérience et la problematique politique pouvaient alors justement déterminer une nouvelle interpretation du mythe. Des problèmes d'actualité pouvaient alors être abordés, de manière plus ou moins directe, et dont le mythe était illustration. C'est à ces moments-là que la tragédie reflète pour nous un aspect de la pensée politique de l'époque: alors elle exerce vraiment sa fonction éducative essentielle: instance globalement neutre, elle met au jour les problèmes ou les realisations de la polis; porte à la conscience l'essence même du politique et exprime peut-être certains mises en garde d'ordre general."
} 


\title{
3. A nósos no vocabulário trágico
}

Para podermos discutir como a doença foi recebida no vocabulário trágico, é preciso apresentar as descrições da peste apresentadas por Tucídides no segundo livro da História da Guerra do Peloponeso. A peste começou em 430 a.C., durante a Guerra do Peloponeso, primeiramente na Etiópia, seguindo para o Egito e chegando até Atenas (TUCÍDIDES, II-48). A doença começou durante o regime de Péricles e levou o general à morte. Tucídides apresenta-nos a peste pela primeira vez no capítulo 47, utilizando a palavra nósos:

\begin{abstract}
Poucos dias após a entrada deles na Ática manifestou-se a peste [nósos] pela primeira vez entre os atenienses. Dizem que ela apareceu anteriormente em vários lugares (em Lemnos e outras cidades), mas em parte alguma se tinha lembrança de nada comparável como calamidade [loimós] ou em termos de destruição de vidas. Nem os médicos eram capazes de enfrentar a doença, já que de início tinham de tratá-la sem lhe conhecer a natureza e que a mortalidade entre eles era maior, por estarem mais expostos a ela, nem qualquer outro recurso humano era da menor valia. As preces feitas nos santuários, ou os apelos aos oráculos e atitudes semelhantes foram todas inúteis, e afinal a população desistiu delas, vencida pelo flagelo (TUCÍDIDES, II-47).
\end{abstract}

O termo nósos possui um amplo espectro semântico, sendo utilizado para designar uma grande diversidade de males, incluindo mas não se limitando a enfermidades físicas — individuais ou de caráter generalizado — e mentais, em especial formas de loucura (LIDDELL; SCOTT, 1940, p. 1181). Walter Burkert adverte para o uso das nossas classificações com relação ao pensamento grego, afirmando que os males físico-psíquicos e os males sociais não eram separados de forma clara pelos gregos e que por vezes a administração da justiça e da cura se fundiam: "Uma transgressão é a fonte da doença, uma doença é o resultado de uma transgressão, seja ela na esfera pessoal, social ou religiosa. Mesmo em grego a palavra nósos, doença, abrange ambos, os distúrbios, enfermidades e sofrimentos físicos e sociais" (BURKERT, 1992, p. 57, tradução nossa) ${ }^{16}$. Tal concepção é preponderante

\footnotetext{
${ }^{16}$ No original: "An offense is the source of illness, illness is the result of an offense, be it in the personal, the social, or the religious sphere. Even in Greek the word nosos, illness, embraces both, the physical and the social disturbances, ailments and sufferings."
} 
para entender uma tragédia como Édipo. Físico, mental, social e religioso não eram campos estanques, e a expressão da doença podia ter todas essas dimensões.

A descrição dos sintomas da peste (TUCÍDIDES, II-49) tem rendido um longo debate sobre em que medida seria possível levar em consideração a descrição sintomatológica efetuada pelo historiador grego. Alguns historiadores tentam pôr à prova a efetividade da descrição da medicina hipocrática, mas carece de sentido comparar a cientificidade de textos de épocas tão distintas. O que é descrito, sendo ou não correspondente a uma sintomatologia moderna, é uma forte febre, manchas vermelhas no corpo, uma evolução da doença para o estômago, com vômitos, diarreia e não sendo incomum apresentar uma grande sede e uma forte insônia.

Tucídides caracteriza a doença como indescritível em sua violência, e o vocabulário advindo da medicina hipocrática mistura-se com um tom profético de um mal que não pode ser compreendido:

O caráter da doença [nósos] desafia qualquer descrição [kreîsson lógou] sendo a violência do ataque, em geral, grande demais para ser suportada pela natureza humana [physin]; por um detalhe ela se mostrou diferente de todos os males comuns: as aves e os quadrúpedes que usualmente se alimentam de cadáveres humanos, ou não se aproximavam deles neste caso (apesar de muitos permanecerem insepultos), ou morriam se os comiam (TUCÍDIDES, II-50).

Tucídides escolhe o termo kreîsson lógou, atribuindo uma força para a nósos que ultrapassa a possibilidade de descrição, que está além das possibilidades do discurso. O fenômeno que se abateu sobre Atenas superava a normalidade das doenças. É um fato além do ordinário que tomou conta da cidade e reduziu suas potencialidades. Tal descrição fará eco como veremos na peste que afeta Tebas, pela sua anormalidade. Mesmo recorrendo à descrição hipocrática dos sintomas, ela é indescritível para a natureza humana (phýsis).

Tucídides aponta também uma espécie de inquietação sobre a origem da enfermidade que ceifava a vida dos atenienses: "Médicos e leigos, cada um de acordo com sua opinião pessoal, todos falavam sobre sua origem provável e apontavam 
causas que, segundo pensavam, teriam podido produzir um desvio tão grande nas condições normais de vida" (TUCÍDIDES, II-48).

Adam Parry demonstra que Tucídides associa a doença a um poder não natural: "ele quer apresentar a doença como uma manifestação inumana ou mesmo sobre-humana, um inimigo demoníaco contra o qual nenhuma arma humana seria útil” (PARRY, 1969, p. 110, tradução nossa). ${ }^{17} \mathrm{~A}$ nósos é uma força descendente que penetra nos corpos e os devasta. Segundo Parry, a doença é na visão tucidideana parte dos males da Guerra. Tucídides afirma que essa instauração da doença traz para a cidade as potencialidades do desequilíbrio, da falta sem lei, da anomia:

De um modo geral a peste [nósema] introduziu na cidade pela primeira vez a anarquia [anomia] total. Ousava-se com a maior naturalidade e abertamente aquilo que antes só se fazia ocultamente, vendo-se quão rapidamente mudava a sorte, tanto a dos homens ricos subitamente mortos quanto a daqueles que antes nada tinham e num momento se tornavam donos dos bens alheios. Todos resolveram gozar o mais depressa possível todos os prazeres que a existência ainda pudesse proporcionar, e assim satisfaziam os seus caprichos, vendo que suas vidas e riquezas eram efêmeras (TUCÍDIDES, II-53).

Como metáfora descritiva, na poesia ou no teatro, a nósos é um tema recorrente para evocar a anormalidade, o mau funcionamento, a desordem (SMITH, 1967, p. 291). Lloyd destaca que a nósos é utilizada também em um sentido social, como um problema para toda a pólis:

tanto nos seus modos sagrados quanto nos profanos, a doença pode afetar não apenas indivíduos singulares como também grupos inteiros. [...] Isto nos leva, então, ao tópico das doenças da sociedade. O vocabulário da doença e da saúde pode ser aplicado à pólis como um todo. Em diagnósticos de por que a pólis está doente, alguns destacam indivíduos como poluidores do corpo político e outros apontam fatores como conflitos internos, stasis, dissensão (LLOYD, 2003, p. 07, tradução nossa) ${ }^{18}$.

\footnotetext{
17 No original: "he wants to present the sickness as an inhuman or even superhuman visitation, a demonic enemy against which no human weapon could avail."

18 No original: "In both its sacred and its profane modes, disease may affect not just single individuals but whole groups. [...] This takes us, then, to the topic of the diseases of society. The vocabulary of sickness and soundness, or disease and health, may be applied to the state as a whole. In diagnoses of why the state is sick, some may concentrate on individuals as pollutants in the body politic, others on factors such as internal strife, stasis, faction."
} 
O vocabulário da doença é usado como representação de uma cidade em desequilíbrio, um elemento de desordem, desagregador do espaço e de qualquer ordem civilizatória, que ameaça a cidade grega. A tragédia não deixou de evocar a força simbólica de tal elemento ${ }^{19}$. Impulsionada pela magnitude da experiência da peste, a nósos tornou-se noção privilegiada para a representação de desequilíbrios da pólis.

Em seu livro In the Grip of Disease: Studies in the Greek Imagination, G.E.R. Lloyd elencou sete elementos interligados da doença que formam uma visão geral e um ponto de partida sobre a complexidade da nósos no pensamento grego, e dos quais aqui destacamos quatro. Lloyd principia pela (1) relação entre a doença e o eu, sobre o corpo humano e o seu funcionamento, pois as ideias sobre funcionamento normal e anormal, saúde e doença, são indissociáveis. Isso leva ao segundo ponto: (2) causalidade e responsabilidade. As respostas podem variar de uma ofensa aos deuses a causas físicas, de uma recompensa ou punição divina pelo comportamento individual ou dos ancestrais a um resultado direto do comportamento de uma pessoa ou grupo (LLOYD, 2003, p. 5-6).

A questão da causalidade remete à (3) poluição e purificação. Podendo a doença ser identificada com uma poluição do indivíduo ou grupo afetado, sua cura passaria por uma purificação ou purga, que poderia ser tanto ritual ou física, por eméticos ou supositórios. Por sua vez, a causa e a cura estão relacionadas à (4) autoridade, a quais pessoas estavam em posição de determinar o porquê de uma doença e o tratamento. Esse não era um domínio exclusivo dos médicos, dada a importância dos sacerdotes e dos templos ligados à cura no período (LLOYD, 2003, p. 6-7).

19 Cabe destacar duas teses nacionais recentes que trabalham a representação da nósos na tragédia grega: o trabalho de Agatha P. Bacelar, Tragoidíai: cantos de cura: representações da doença nos cultos dionisíacos e em tragédias de Sófocles (2018), e o trabalho de Mateus Dagios, Pólis enferma: Nósos e a representação do lógos sofistico nas tragédias Filoctetes de Sófocles e Orestes de Eurípides (2019). 
Mitchell-Boyask argumenta que o uso da palavra nósos foi tornando-se cada vez mais proeminente no texto trágico depois dos anos da peste, sendo então a experiência da doença marcante no imaginário ateniense, principalmente nas tragédias de Sófocles. O autor defende que nas tragédias "as doenças [das personagens] são sintomáticas da sua relação problemática com as suas comunidades, e a única forma de curar a cidade é purgá-la da infecção ou reequilibrar os componentes da cidade de forma a fazê-los funcionar em maior harmonia" (MITCHELL-BOYASK, 2012, p. 319, tradução nossa) ${ }^{20}$.

Como abordaremos no próximo tópico, o herói trágico torna-se símbolo de uma cidade doente. No caso de Édipo, a própria presença dele desequilibra o ciclo vital da cidade. A peste de Tebas é um sintoma de um desacordo na governança da cidade. O espaço da cidade é desestruturado por uma força desagregadora da ordem, que está associada à monstruosidade do crime de Édipo.

\section{Doença e espacialidade no Édipo Tirano}

Nesta terceira parte, discutiremos como a temática da doença é relacionada ao herói trágico e como a peste molda a espacialidade no texto trágico. O termo nósos aparece 14 vezes na peça, distribuídas de forma desigual. As 8 ocorrências relevantes para a análise proposta concentram-se nos 300 primeiros versos. Em relação às partes quantitativas da Poética de Aristóteles (Poética XII, 66), a tragédia Édipo Tirano pode ser resumida da seguinte maneira:

Prólogo, parte que antecede a entrada do coro (Édipo Tirano, vv. 1-150) ${ }^{21}$. Tebas está devastada pela peste. O sacerdote de Zeus, crianças e velhos estão ajoelhados

\footnotetext{
20 No original: "Their diseases are symptomatic of their problematic relationships with their communities, and the only way to cure the city is to purge it of the infection or to rebalance the city's $[\ldots]$ components so as to make them work in greater harmony."

21 A edição de Édipo Tirano citada é a publicada pela editora Todavia em 2018, com tradução de Leonardo Antunes.
} 
diante do palácio de Tebas. Eles suplicam a Édipo, que antigamente os libertou do jugo da Esfinge, que pinha fim à misteriosa doença. Édipo diz que enviou Creonte para consultar o oráculo de Apolo. Creonte retorna trazendo uma resposta favorável. Tebas retornará à normalidade quando for descoberto quem assassinou o antigo rei Laio. Édipo assume o compromisso de descobrir quem cometeu tal ato e convoca uma assembleia de tebanos.

Párodo, canto que acompanha a entrada do coro (vv. 151-215). Os anciãos fazem sua entrada suplicando que expulsem Ares, o deus da peste.

Episódio 1, parte em diálogo (vv. 216-462). Disposto a vingar o antigo rei Laio, Édipo amaldiçoa o autor do crime e oferece recompensa e gratidão a quem tiver alguma informação sobre o ato, prometendo também castigar quem tentar ocultá-lo.

O coro pede a Édipo que apele a um antigo adivinho cego, Tirésias, de idade avançada e grande sabedoria. Tirésias entra em cena puxado por uma criança e inicialmente recusa-se a falar. Recebendo ataques de Édipo, ele anuncia a Édipo que o assassino que busca é ele mesmo. Indignado com a afronta, Édipo expulsa Tirésias, também o acusando de tramar a história com Creonte.

Estásimo, canto do coro (vv. 463-512). O coro revela-se também perturbado por tamanha acusação, não acreditando nas palavras de Tirésias.

Episódio 2 (vv. 513-862). Creonte chega para que se dissipe o mal-entendido e diz que não tem ligações com Tirésias. Édipo não acredita nas palavras de Creonte, acusa o cunhado de demasiada ambição e diz que ele merece morte ou expulsão de Tebas. Jocasta entra em cena e repreende os dois por quererem aumentar os males da cidade em uma época de peste. Ao saber que a cidade apenas retornaria ao normal depois de descobrirem quem matou Laio, Jocasta conta que os oráculos previram que o antigo chefe de Tebas morreria pelas mãos do seu próprio filho e que por isso ele havia sido abandonado em uma montanha. Laio morrera anos mais tarde em uma encruzilhada de três caminhos, por causa de vários bandidos. Édipo fica perturbado 
com o detalhe da encruzilhada e conta que deixou Corinto para frustrar um oráculo segundo o qual ele mataria o pai e desposaria a mãe. Ao fugir, encontrou-se com um velho, cuja descrição corresponde a de Laio, em um encontro de três caminhos, matando o homem e seus empregados por causa de um desentendimento. Para aplacar suas dúvidas, Édipo ordena que tragam à sua presença o camponês que testemunhou a morte de Laio.

Estásimo (vv. 863-910). O coro censura a býbris de Édipo e a desmedida do seu ato.

Episodio 3 (vv. 911-1085). Entra em cena um mensageiro de Corinto, anunciando a morte de Pólibo, rei de Corinto e suposto pai de Édipo. O parricídio parece afastado, mas Édipo continua a temer um possível incesto. Para tranquilizar Édipo, o mensageiro revela que ele não é filho de Pólibo e Mérope. Ele mesmo guardava rebanhos quando recebeu antigamente das mãos de um pastor tebano o desventurado recém-nascido, levando-o aos soberanos de Corinto que não conseguiam ter filhos e que o adotaram. Apesar das súplicas de Jocasta, que compreendeu o terrível da situação, Édipo manda convocar o pastor tebano. Horrorizada, Jocasta entra no palácio.

Estásimo (vv. 1086-1109). Em um breve canto, o coro imagina que Édipo poderia ser o filho de um deus e de uma ninfa.

Episódio 4 (vv. 1110-1185). Édipo descobre o horror de seu destino. O camponês que acompanhava Laio no dia de sua morte revela ser o pastor que entregou a criança ao mensageiro de Corinto. Édipo descobre que é um parricida e que desposou sua mãe.

Estásimo (vv. 1186-1222). Comovido com a reviravolta, o coro reflete sobre a desgraça de quem outrora foi salvador e hoje revela a fragilidade da felicidade humana. 
Exxodo, saída do coro (vv. 1223-1530). Um arauto vem anunciar que Jocasta se enforcou e Édipo furou os próprios olhos ao vê-la morta. Édipo aparece ensanguentado e suplica que permitam que ele viva longe de Tebas. Em seu último canto, o coro pondera que nenhum homem pode dizer que foi feliz até estar no último dia sua vida (THIERCY, 2009, p. 31-34).

A peça principia com Édipo recebendo os cidadãos de Tebas, que se prostram diante do governante pedindo cura e providências sobre a doença que se abateu sobre Tebas:

\author{
Édipo: \\ Filhos de Cadmo ancião, recente prole, \\ Porque vós vos lançais perante mim, prostrados, \\ Trazendo por coroas ramos súplices? \\ A pólis súbito preenche-se de incenso; \\ súbito há gritos de peã pedindo cura. \\ Julguei que não devia por relatos, filhos, \\ alheios informar-me. Logo eu próprio venho: \\ o célebre entre todos, Édipo me chamam. (vv. 1-8)
}

A grandiosa entrada de Édipo é sinal do prestígio do governante na cidade de Tebas. Ele é o centro simbólico do poder, célebre entre todos por seus feitos que envolvem o saber. Ele decifrou o enigma da Esfinge e apresenta-se como cuidadoso com os seus. Menciona os cantos de cura que permeiam a cidade e coloca-se como ciente da situação. A cena marca a presença de um arco etário: estão presentes todas as temporalidades da cidade, jovens, velhos e crianças. Situada perante o palácio de Tebas, a espacialidade da cena remete a um governante que encontra seus súditos para decidir-lhes o destino. Em um regime como o ateniense, que era exercido pela participação, a cena traz um emblema de tirania, de algo antidemocrático, em uma figura que contempla e reúne tamanhos poderes sobre o dêmos. O sacerdote chefe do coro descreve a situação de Tebas:

\footnotetext{
Sacerdote:

pois a cidade, como vês, demasiado já se abala: nem pode mais erguer a fronte das profundezas de uma revolvente morte. Fenece junto à flor dos frutos pelo chão; fenece junto ao gado novo no rebanho e aos filhos natimortos. Foi o deus do fogo
} 


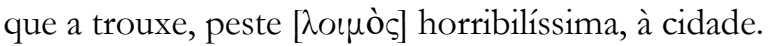

Ele esvazia a casa cadmeia e o breu

do Hades com gemido e lágrima enriquece. (vv. 22-30)

A primeira palavra empregada para evocar a peste é loimós. De acordo com Mitchell-Boyask, é uma palavra rara no vocabulário grego do século $\mathrm{V}$ a.C. para descrever doenças ou a peste que assolou Atenas:

Loimós é uma palavra extremamente rara no século $\mathrm{V}$, e os poetas, especialmente após $430 \mathrm{AEC}$, evitam-na de tal maneira que é preciso concluir que há uma certa forma de superstição por trás da sua ausência. Com a peste ateniense ainda em andamento ou recentemente encerrada, o efeito dessa palavra, dita por uma autoridade religiosa, depois de uma preparação tão cuidadosa por Sófocles, deve ter sido bastante devastador (MITCHELL-BOYASK, 2012, p. 321, tradução nossa) ${ }^{22}$.

Édipo afirma que a doença que assola Tebas também o aflige. Édipo colocase como enfermo, e a doença da cidade passa a ser a sua nósos. Como governante, ele diz sentir a doença de todos:

\author{
Édipo: \\ Pobres filhos! Conheço bem - não desconheço - \\ o que viestes desejando, pois bem sei \\ que todos adoecem, mas, adoecendo, \\ nenhum de vós está doente [voбعĩ] igual a mim, \\ pois para vós a dor vos vem singularmente: \\ sozinho, cada qual por si. Contudo, a minha \\ alma por mim, por ti e pela pólis sofre, \\ de modo que, do sono, vós não me acordais. (vv. 58- 65)
}

Como herói enfermo, Édipo passa a se colocar como protagonista de uma

cidade enferma. Como salientamos, existe nas tragédias uma relação entre a doença e os males da cidade. Na busca pelo equilíbrio, a pólis deve ou encontrar uma cura para o herói ou purgá-lo do seu convívio. A peste que afeta Tebas é uma praga que altera ciclos naturais, filhos natimortos, fenecimento das plantas e das criações. A cidade encontra-se desarranjada em sua ordem. É uma doença de esgotamento dos espaços,

\footnotetext{
${ }^{22}$ No original: "Loimos is an extremely rare word in the fifth century, and poets, especially after 430 BCE, avoid it to such an extent that one must conclude there is some form of superstition behind its absence. With the Athenian plague still going on or recently ended, the effect of this word, spoken by a religious authority, after Sophocles has so carefully built towards it, must have been quite shattering."
} 
esterilidade e carência. Édipo não sabe, mas seu crime é a causa da doença. Seu governo e seus atos atentam contra uma ordem cósmica. Mesmo desordenado, o herói é descrito como salvador (sotér), e contraditoriamente a ele é delegada a missão de dar fim à peste (nósos):

\author{
Sacerdote: \\ Meus filhos, levantemo-nos, pois o favor \\ que aqui nos trouxe está por este prometido. \\ Possa Febo, emitente dessas profecias,

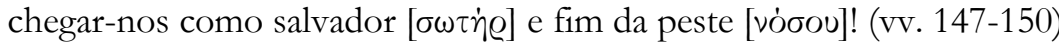

Além da crise cósmica, causada pelo parricídio e pelo casamento com a mãe, Édipo é ainda um usurpador do poder, um tyrannos, um governante que chegou ao poder de forma não convencional e abusa de sua condição. Mesmo que goze de prestígio e lhe seja atribuída a função de salvar a cidade, Édipo, sem saber, é um tirano. Bernard Knox salienta:

Há um aspecto de sua posição em Tebas que justifica plenamente o termo: ele não é (tanto quanto se sabe no início da ação) o sucessor hereditário ao trono, mas um estrangeiro (ksenos, como ele próprio diz) que, mesmo não pertencendo à linhagem real nem sendo tebano nativo, chegou ao poder supremo (KNOX, 2002, p. 44).

O Tirano corrói o espaço da ágora. Se a praça ateniense é o centro dos debates e o local em que acontecem as decisões sobre os rumos da cidade, na peça vemos Édipo tomar todas as decisões e não compartilhar a responsabilidade. No livro Carne e Pedra, Richard Sennett descreve a ágora como um espaço no qual "não havia nenhuma voz dominante" (SENNETT, 2008, p. 52). No Édipo Tirano, Édipo ocupa todos os espaços de fala, e todos aqueles que ousam contrariá-lo são expostos e reprimidos. A tirania de Édipo aniquila a possibilidade de uma cidade democrática com equilíbrio de forças, o que não passaria despercebido para o público ateniense.

A situação de Édipo, um intruso que, com proeza individual, conquista o poder em Tebas, pode ser compreendida como uma das causas da peste. A tirania não era vista com bons olhos pelos atenienses, que tinham um regime resguardado na força do dêmos. O coro salienta que "Híbris produz o tirano" (Édipo Tirano, v. 873), ou 
seja, a desmedida e a violência engendram um usurpador de poder. Há um desequilíbrio que afeta toda a cidade:

\author{
Coro: \\ Ai! Incontáveis são os males que eu \\ trago. A cidade toda enferma [voøะĩ] está. \\ Nem na mente eu encontro uma arma \\ para a defesa; nem vejo crescerem os \\ frutos mais da terra famosa; nem filhos \\ da dor do parto, gritante, às mulheres resultam. (vv. 169-174)
}

Devemos comparar se a doença descrita na tragédia tem semelhanças com a que afetou Atenas. Primeiramente, é preciso atentar para a natureza do vocabulário trágico. A tragédia não é um texto descritivo da realidade, mas um texto performático elaborado para um festival ritualístico. Tucídides, quando expõe as dimensões da peste no livro II da História da Guerra do Peloponeso, preocupa-se com uma dimensão de verdade que não existe no texto trágico. Bernard Knox destaca que existem semelhanças vocabulares, ambos partindo do mesmo termo, nósos, mas os dois textos têm funções diferentes (KNOX, 1956, p. 135). Para Rehm, o prólogo com a descrição da peste tebana não deixaria de evocar aos atenienses a peste em seu próprio espaço cotidiano:

O fato de que a peça começa com duas cenas focadas na peste faz com que seja altamente improvável que o público ateniense visse a Tebas de Sófocles como "dramaticamente diferente de si". [...] Ao colocar dois grupos sucessivos entrando no teatro com notícias da epidemia, Sófocles combinou a Tebas mítica do drama com a Atenas assolada pela peste, uma cidade que no momento sofria com os efeitos daquela "provação mais terrível e calamitosa" (REHM, 2002, p. 227, tradução nossa) ${ }^{23}$.

A peste da tragédia emprega um manancial mítico de desestrutura, de maldições que desregulam ciclos de vida, nas mulheres, nas criações e nas colheitas.

\footnotetext{
${ }^{23}$ No original: "The fact that the play opens with two scenes focused on the plague makes it highly unlikely that the Athenian audience saw Sophocles' Thebes as "dramatically other than itself." [...] By having two successive groups enter from outside the theater with news of the epidemic, Sophocles merged the mythic Thebes of his drama with plague-ridden Athens, a city suffering at the time from the effects of "that most calamitous and awful visitation."
} 


\section{Espacialidades}

A desarmonia da doença é apresentada como a desestruturação dos espaços e dos corpos.

O espaço cênico da tragédia representa duas grandes esferas da ordem social ateniense: o oikes, espaço doméstico, e o ambiente público da comunidade de cidadãos. Na tragédia, esses espaços são transformados à medida que Édipo avança em sua investigação. A configuração da peste na cidade e a enfermidade que Édipo afirma também sofrer modificam a realidade do espaço. Do estado elevado até a miséria, acompanhamos a metamorfose da pólis. O lugar diante do palácio onde o coro suplicante pede providências transforma-se no lugar em que Édipo decreta a condenação do assassino de Laio e posteriormente em um local de ágon, quando Édipo e Tirésias discutem. Torna-se então um lugar de poder quando Édipo condena Creonte à morte ou expulsão e, por fim, um lugar de revelação da monstruosidade do seu destino.

Em relação ao oikos, embora ele não seja cenário no palco, ele está presente em menções ao lugar onde Édipo e Jocasta repousam e ao local em que ela se mata e ele fura os próprios olhos. São evocados também os espaços das colheitas, do reino de Corinto e das montanhas aonde Édipo foi levado pelo pastor tebano e recolhido pelo mensageiro.

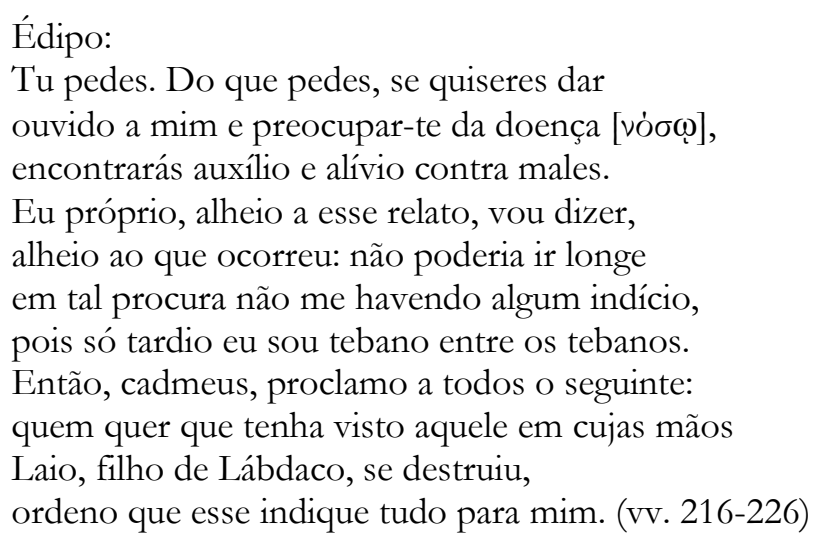

Seguindo o oráculo que anunciou a cura da cidade apenas quando o assassino de Laio fosse descoberto, Édipo começa sua investigação com um decreto. A cura da doença que destrói Tebas é a chave para o equilíbrio da pólis, e o desequilíbrio é a 
origem da doença. No cerne das relações simbólicas entre a doença e a pólis estão princípios comuns: tanto a saúde do corpo quanto o bom funcionamento da pólis eram relacionados no século $\mathrm{V}$ a.C. com ideias de equilíbrio e isonomía (igualdade), sendo o desequilíbrio muitas vezes causado por um elemento externo ou interno que deixa de existir em harmonia com os demais.

Do ponto de vista da medicina hipocrática, a doença era desequilíbrio, e a cura do corpo estava ligada a um regresso ao equilíbrio, "do mesmo modo que o desequilíbrio entre os vários elementos que constituem a cidade é fonte de perturbação e só pode ser ultrapassado pela igualdade perante a lei (isonomía)" (MOSSÉ, 1997, p. 46). O desequilíbrio consistia no isolamento de um dos componentes do que deveria ser uma mistura equilibrada, no efeito desestabilizador de fatores externos ou no excesso ou déficit de um dos elementos constitutivos do corpo (MOSSÉ, 1997, p. 45-6).

A investigação de Édipo tenta justamente isolar esse ponto de desequilíbrio para aplacar os sintomas. O que o herói trágico não percebe é que ele é o tumor que causa desordem no corpo cívico. É a sua presença que corrompe a terra e o lugar do governante. Ao conversar com o cego Tirésias, ele revela ao sábio o motivo da sua investigação e conta com a sabedoria do ancião para poder trazer alívio aos males da cidade:

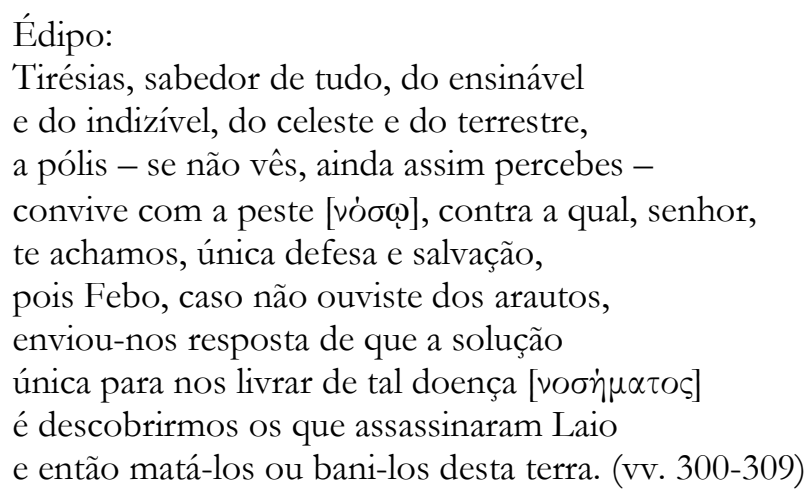

Inicialmente, Tirésias decide não revelar a origem dos males de Tebas, não revelar a Édipo que é ele a fonte do problema da cidade. Édipo irrita-se com o velho 
adivinho, ameaçando-o e acusando-o. Depois de uma violenta discussão, Tirésias revela ao herói:

\author{
Tirésias: \\ É mesmo? Pois ordeno que tu obedeças \\ ao teu próprio decreto e até o fim dos dias \\ nunca mais fales nem a esses nem a mim!

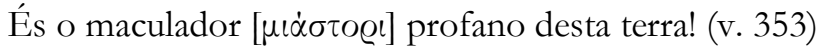

Édipo recebe a notícia de que é responsável pela poluição (miasma) da cidade, o que em um primeiro momento não é compreendido. Contudo, o restante da peça mostra a Édipo que Tirésias tem razão em sua afirmação e que sua presença é uma mácula, o que faz com que ele peça pelo exílio:

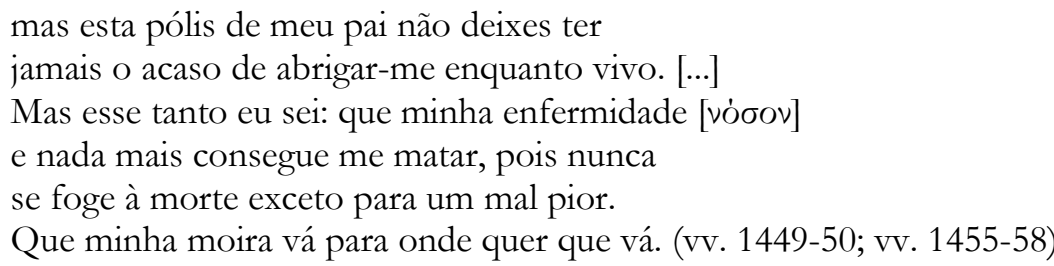

O percurso de Édipo é um caminho de queda. Ele principia a peça como salvador, homem divinizado, e entre incensos e súplicas condena o assassino de Laio ao ostracismo. No fim, descobre que é o motivo dos males da cidade, portador de uma mácula, e termina cego, poluído e destruído. De homem sábio a joguete dos deuses, Édipo consegue salvar Tebas da nósos, e sua atuação torna-se a de um pharmakós, um bode expiatório. Vernant associa a purificação de Tebas em sua relação com o herói com o rito anual de purificação:

A cerimônia tinha lugar no primeiro dia da festa das Targélias, no dia 6 Thargelión. Os dois pharmakoi usando colares de figos secos (pretos ou brancos segundo o sexo que representavam) desfilavam através de toda a cidade. Batia-se no sexo deles com cebolas albarrãs, figos e outras plantas selvagens, depois eles eram expulsos. Talvez, ao menos na origem, eles fossem condenados à morte por lapidação, seus cadáveres queimados, suas cinzas dispersas (VERNANT, 1999c, p. 88).

A peste reconfigurou a cidade, transformou espaços produtivos em campos esgotados, esterilizou as mulheres, tornou o sábio o mais pária dos homens. Édipo em sua destruição termina purificando a cidade. Édipo Tirano é uma tragédia 
construída com relações ambíguas. Procuramos demonstrar como a doença desempenha um papel fundamental na configuração do texto e do espaço dramático, em que Sófocles transforma uma Tebas mítica poluída pelo crime da maldição em um espaço de tirania e em uma Atenas assolada pela peste e por desordens políticas. Os atenienses ao assistirem Édipo ainda estavam mergulhados em uma experiência coletiva da doença, e expurgá-la da pólis e recuperar o equilíbrio talvez fosse o que mais desejassem.

\section{Considerações finais}

Começamos o texto com uma epígrafe do famoso ensaio de Susan Sontag Doença como metáfora, em que a autora rastreia descrições metafóricas da tuberculose e do câncer e demonstra como a sociedade projeta determinados anseios no doente e na doença. O artigo em seus objetivos é devedor do ensaio de Sontag. Nossa problemática tomou a doença como um elemento da paisagem mítica na tragédia Édipo Tirano para demonstrar como a nósos se desenvolve na tragédia com um problema para o herói trágico e para a espacialidade da pólis. A doença no texto é vetor de um problema, espacializa questões, e resolvê-la é retomar o equilíbrio.

A tragédia como experiência ritualística e cívica propõe uma reflexão para a comunidade de cidadãos. O Édipo Tirano de Sófocles aborda perguntas sobre a natureza do poder, sobre o tipo de conhecimento e sobre as desmedidas do tirano. Na tragédia, cidade-doente e herói-doente entrecruzam-se. O espaço cênico de Tebas evocava para os atenienses os males da peste que sofria. A cidade da tragédia sofre com uma doença que esgota suas forças produtivas e esteriliza seu futuro, enquanto Atenas sofrera com uma peste e sofria com uma guerra que parecia não ter bom término. Assim, o espaço da tragédia sofocleana apresenta uma cidade que tentava lidar com forças desfragmentadoras e anárquicas associadas à doença. 
Muitos significados têm sido atribuídos a Édipo, um homem-enigma que decifrou a Esfinge enquanto fugia para tentar enganar um oráculo, mas que acaba destruído por ele. Édipo é um homem enfermo, e seus atos mesmo que involuntários adoecem Tebas. Discutir a Atenas em que Édipo Tirano foi composto e encenado é encontrar mesmo que de forma acidental nossas próprias posturas frente a uma pandemia. A doença de Tebas mostrou que seu governante, um tirano saudado como salvador, era a origem dos males da cidade, e a Covid-19 também tem mostrado algo sobre nossos governantes. Basta saber se como Tebas conseguiremos retomar o equilíbrio.

\section{REFERÊNCIAS}

ANDERSON, Michael J. Myth. In: GREGORY, Justina (ed.). A companion to Greek tragedy. S/l: Blackwell Publishing, 2005. pp. 121-135.

BACELAR, Agatha Pitombo. Tragoidíai: cantos de cura: representações da doença nos cultos dionisíacos e em tragédias de Sófocles. 2018. 322 f. Tese (Doutorado em Linguística) - Universidade de Brasília, Brasília, 2018.

BURIAN, Peter H. Myth into muthos: the shaping of tragic plot. In: EASTERLING, P.E (ed.). The Cambridge Companion to Greek Tragedy. Cambridge: CUP, 1997. pp. 178-208.

BURKERT, Walter. The Orientalizing Revolution. Cambridge (US): Harvard UP, 1992.

CUSSET, Christophe. La tragédie grecque. Paris: Éd. du Seuil, 1997.

DAGIOS, Mateus. Pólis enferma: Nósos e a representação do lógos sofístico nas tragédias Filoctetes de Sófocles e Orestes de Eurípides. 2019. 255 f. Tese (Doutorado em História) - Universidade Federal do Rio Grande do Sul, Porto Alegre, 2019.

DUMANOIR, Jean-Richard. Les mondes virtuels de Sophocle. In: Le théâtre grec antique : la tragédie. Actes du 8ème colloque de la Villa Kérylos à Beaulieu-sur-Mer les 3 \& 4 octobre 1997. Paris: Académie des Inscriptions et Belles-Lettres, 1998. pp. 59- 84. (Cahiers de la Villa Kérylos, 8)

FINLEY, M. I. Democracia antiga e moderna. Rio de Janeiro: Graal, 1988. 
GOLDHILL, Simon. The language of tragedy: rhetoric and communication. In: EASTERLING, P.E (ed.). The Cambridge Companion to Greek Tragedy. Cambridge: CUP, 1997. pp. 127-150.

GRIMAL, Pierre. O Teatro Antigo. Lisboa: Edições 70, 1986.

KNOX, Bernard. The Date of the Oedipus Tyrannus of Sophocles. The American Journal of Philology. Vol. 77, No. 2, 1956. pp. 133-147.

KNOX, Bernard. Édipo em Tebas. São Paulo: Perspectiva, 2002.

LABEY, Pauline. L'histoire du malade. Croisement de deux anthropologies. L'Atelier du Centre de Recherches Historiques. S/1, 06 mai 2010.

LAPLANTINE, François. Antropologia da doença. São Paulo: Martins Fontes, 1991.

LE GOFF, Jacques. As doenças têm história. Lisboa: Terramar, 1997.

LIDDELL, Henry; SCOTT, Robert. A Greek-English Lexicon. Oxford: OUP, 1940.

LLOYD, G.E.R. In the Grip of Disease: studies in the Greek Imagination. Oxford: Oxford University Press, 2003.

MARSHALL, Francisco. Édipo filósofo, inocente responsável. Filosofia Unisinos. S/1, n. 8, pp. 49-59, 2007.

MEIER, Christian. La naissance du politique. Paris: Gallimard, 1996.

MEIER, Christian. De la tragédie grecque comme art politique. Paris: Les Belles Lettres, 2004.

MITCHELL-BOYASK, Robin. Heroic Pharmacology: Sophocles and the language of Early Greek Medicine. In: MARKANTONATOS, Andreas (ed.). A Companion to Sophocles. Leiden: Brill, 2012.

MOSSÉ, Claude. As lições de Hipócrates. In: LE GOFF, Jacques. As doenças têm história. Lisboa: Terramar, 1997.

PARRY, Adam. The Language of Thucydides' Description of the Plague. Bulletin of the Institute of Classical Studies. No. 16, pp. 106-118, 1969.

REHM, Rush. The Play of Space: Spatial Transformation in Greek Tragedy. New Jersey: Princeton University Press, 2002. 
SENNETT, Richard. Carne e pedra: o corpo e a cidade na civilização ocidental. Rio de Janeiro: Record, 2008.

SMITH, Wesley D. Disease in Euripides' Orestes. Hermes. 95 Bd., H. 3, pp. 291 307, 1967.

SÓFOCLES. Édipo Tirano. Tradução de Leonardo Antunes. São Paulo: Todavia, 2018.

SOPHOCLE. Tragédies. Tome II : Ajax - CEdipe Roi - Electre. Texte établi par : Alphonse Dain, Jean Irigoin, Traduit par: Paul Mazon. Paris: Les Belles Lettres, 1981.

SONTAG, Susan. Doença como metáfora. AIDS e suas metáforas. São Paulo: Companhia das Letras, 2007.

THIERCY, Pascal. Tragédias gregas. Porto Alegre: L\&PM, 2009.

THUCYDIDE. La Guerre du Péloponnese. Texte établi et traduit par Jacqueline de Romilly. Livres II et IV. Paris: Belles Lettres, 1962.

TUCÍDIDES. História da Guerra do Peloponeso. Tradução de Mario da Gama Kury. Brasília: Editora da Unb, 1987.

VERNANT, Jean-Pierre. Édipo sem Complexo. In: VERNANT, Jean-Pierre; VIDAL-NAQUET, Pierre. Mito e tragédia na Grécia Antiga. São Paulo: Perspectiva, 1999a. pp. 53-71.

VERNANT, Jean-Pierre. O Deus da Ficção Trágica. In: VERNANT, Jean-Pierre; VIDAL-NAQUET, Pierre. Mito e tragédia na Grécia Antiga. São Paulo: Perspectiva, 1999b. pp. 157-162.

VERNANT, Jean-Pierre. Ambigüidade e Reviravolta. Sobre a Estrutura Enigmática de Édipo-Rei. In: VERNANT, Jean-Pierre; VIDAL-NAQUET, Pierre. Mito e tragédia na Grécia Antiga. São Paulo: Perspectiva, 1999c. pp. 73-99. 